\title{
EUGENIUSZ KoŚMICKI
}

\author{
Katedra Nauk Spolecznych i Pedagogiki \\ Wydział Ekonomiczno-Społeczny \\ Uniwersytet Przyrodniczy $w$ Poznaniu \\ Wojska Polskiego 28, 60-637 Poznań \\ E-mail:e.h.kosm@gmail.com
}

\section{O ŻYCIU I DZIEŁACH AUSTRIACKIEGO ETOLOGA PROF. IRENÄUSA EIBLA-EIBESFELDTA (15 CZERWCA 1928 - 2 CZERWCA 2018)}

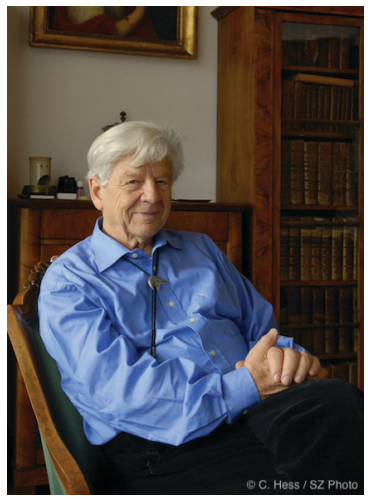

O ŻYCIU PROFESORA

I. EIBLA-EIBESFELDTA

Profesor Irenäus Eibl-Eibesfeldt należał do najwybitniejszych współczesnych biologów zajmujacych się problematyka zachowania się ludzi i zwierząt. Do najbardziej znanych jego prac naukowych należą podręczniki poświęcone tej tematyce (EIBL-EIBESFELDT 1967, 1984c, 1997a, 1998b). Obok wielu opracowań ściśle biologicznych, Eibl-Eibesfeldt jest też autorem interesujacych książek o charakterze filozoficzno-społecznym, w których podejmował tematy dotyczace problemów społeczeństwa, gospodarki i ochrony środowiska (EIBL-EIBESFELDT 1988c, 1994b, 1997b, c, 1998c, 2000). W swoich pracach nie unikał trudnych problemów społecznych i ekologicznych związanych $z$ gwałtownymi zmianami ludzkiego zachowania w wyniku rozwoju kultury, zmiany miejsca człowieka w przyrodzie i w społeczeństwie. Należał do twórców etologii człowieka i był długoletnim kierownikiem znanej na całym świecie placówki badawczej Forschungsstelle für $\mathrm{Hu}-$ manethologie w Towarzystwie Maxa Plancka, znajdujacej się w Andechs koło Starnbergu (Bawaria). Był on też profesorem na Uniwersytecie Monachijskim (Humanwissenschaftliches Zentrum der Ludwig-Maximilian-Universität München). W dniu 2 czerwca 2018 r. prof. I. Eibl-Eibesfeldt zmarł kilkanaście dni przed swoimi urodzinami.

Napisał 19 książek jako samodzielny autor i opublikował ponad 500 artykułów w naukowych czasopismach specjalistycznych. Jego książki zostały przetłumaczone na wiele języków, w tym także na język polski. Dwie $z$ nich stały się światowymi bestsellerami (Miłość i nienawiść 1970, 1993a i Zaprogramowany człowiek 1973, 1976a, 1984a, 1986).

Irenaüs Eibl-Eibesfeldt urodził się 15 czerwca 1928 r. w Wiedniu. Dzieciństwo spędził w podwiedeńskiej miejscowości Kierling. Jego ojciec, Anton, był profesorem botaniki w wyższej szkole ogrodniczej. Pomimo wczesnej śmierci (w 1941 r.), wywarł on duży wpływ na późniejszego uczonego. Jego matka, Maria $z$ domu von Hauninger, miała duże zdolności artystyczne w zakresie muzyki, poezji i malarstwa. Rodzice nazywali młodego Irenäusa „Renki” i tego zdrobnienia używał przez całe życie. Tak zwracali się do niego członkowie rodziny i przyjaciele (EIBL-EIBESFELDT 1992, 1994a). Już w okresie wczesnego dzieciństwa Eibl-Eibesfeldt interesował się obserwacja i hodowla zwierząt. Jego rodzice poczatkowo $z$ sympatia odnosili się do ruchu narodowego socjalizmu, wi- 
dzac w nim możliwość odrodzenia Niemiec jako wielkiego mocarstwa. Pozytywnie przyjęli więc przyłączenie Austrii do Niemiec w 1938 r. Nie brali jednak żadnego udziału w organizacjach nazistowskich. W wieku 15 lat młody I. Eibl-Eibesfeldt powołany został do służby wojskowej, pełniac rolę pomocnika kanoniera w obronie przeciwlotniczej. W Wiedniu zastał go upadek faszyzmu i wyzwolenie miasta przez armię radziecką. Duży wpływ wywarły na niego ogromne masy niemieckich przesiedleńców ze Wschodu, a także wiadomości o zbrodniach faszyzmu.

Od 1946 r., dzięki swojemu przyjacielowi Wolfgangowi Schleidtowi, nawiazał kontakt z Otto Koenigiem, stając się wkrótce jego współpracownikiem w Stacji Biologicznej Wilhelminenberg koło Wiednia, zwiąanej $z$ ogrodem zoologicznym w Schönbrunn. Duży wpływ na ukształtowanie się jego zainteresowań badaniem ssaków wywarły obserwacje młodego borsuka i inwazje myszy. Właściwa jednak problematyka badawcza odnosiła się początkowo do płazów, a badania nad rozmnażaniem się ropuch stanowiły podstawę jego pracy doktorskiej. Jego nauczycielami akademickimi byli: Ludwig Bertalanffy, Wilhelm von Marinelli, Otto Storch, a przede wszystkim Otto Koenig i Konrad Lorenz. W latach 1951-1969 Eibl-Eibesfeldt był asystentem naukowym K. Lorenza, najpierw w Bouldern, a następnie od 1957 r. w Seewiesen (w Bawarii) (EIBL-EIBESFELDT 1992a, 1994a).

W Wilhelminenbergu Eibl-Eibesfeldt stał się etologiem. Poczatkowo interesowały go głównie typowe dla danego gatunku sposoby zachowania, które zaczęto określać „etogramami". Za równie ważne uważał problemy komunikowania się zwierząt, a także rozwój zachowania w okresie ontogenezy. Taki kierunek badań doprowadził do eksperymentów, które wyjaśniły problem dziedziczenia i uczenia się. Niemiecki zoolog Oskar Heinroth wykazal po raz pierwszy, że wzorce zachowania, podobnie jak struktury anatomiczno-morfologiczne, sa cechami gatunkowymi. Opierajac się na badaniach Heinrotha, K. Lorenz rozwinal swoje koncepcje zachowań wrodzonych jako podstawę etologii. Koncepcje etologów sprzeczne były $z$ założeniami rosyjskiej refleksologii (W. Bechterew, J. Pawłow) i amerykańskiego behawioryzmu. Jego czołowy przedstawiciel, psycholog J. B. Watson, traktował zachowanie sie zwierzat i ludzi jako podlegajace schematowi bodziec-reakcja. Behawioryści odrzucali pojęcie „zachowania wrodzonego" jako nieużyteczne w badaniach naukowych. Na tle tej dyskusji kształtowały się poglacdy naukowe młodego uczonego. Interesował się on nie tylko zachowaniami wrodzonymi, lecz także proble- matyka uczenia się (EIBL-EIBESFELDT 1992a, 1994a).

Gdy w 1948 r. Konrad Lorenz wrócił z rosyjskiej niewoli, większość jego współpracowników przeniosła się do Altenbergu, gdzie Lorenz założył Instytut Porównawczych Badań nad Zachowaniem. Eibl-Eibesfeldt został współpracownikiem K. Lorenza w 1949 r., a rok później wraz $z$ żona, opuścił ostatecznie ukochany Wiedeń, aby $z$ Lorenzem badać zachowania zwierząt w Buldern w Westfalii. Z Wiedniem czuł się związany bardzo emocjonalnie, a Niemiec nie traktował nigdy jako zagranicy, ale jedynie jako dalsza ojczyznę. Sam zreszta określał siebie jako „Austriaka, Niemca, Europejczyka” (EIBL-EIBESFELDT 1991b, 1993b). W Buldern zajmował się głównie badaniem wiewiórek, a także porównawczym badaniem szczurów. Stopniowo swoje zainteresowania zaczał koncentrować na człowieku.

W 1954 r. odbył ekspedycje naukowa jachtem „Xarifa” po Morzu Karaibskim i do Wysp Galapagos. Odkrył wtedy „symbioze czyszczenia” pomiędzy rybami. Fascynowały go, tak jak K. Darwina, endemiczne dla tych rejonów gatunki zwierzat. Podczas wyprawy Eibl-Eibesfeldt znalazł liczne ślady niszczenia przyrody, głównie w wyniku szybkiego wzrostu liczebności miejscowej ludności. Opracował specjalny memoriał do UNESCO i Międzynarodowej Unii Ochrony Przyrody (IUCN) w Brukseli, w którym zaproponował podjęcie działań ochronnych, przez stworzenie rezerwatu i założenie stacji biologicznej (EIBL-EIBESFELDT 1969, 1991a). W wyniku tych działań założono w Brukseli fundację Charles Darwin Foundation, a na Wyspie Santa Cruz biologiczna stację badawcza Charles Darwin Station. Ekspedycja naukowa „Xarifa” pogłębiła wiedzę młodego uczonego w zakresie etologii i filogenezy zwierzat.

Instytut w Buldern był od początku pomyślany jako miejsce tymczasowe. W 1957 r. badacze przenieśli się do Seewiesen koło Starnbergu, a powstały tam Instytut Lorenza stał się częścia Towarzystwa Maxa Plancka. W tym okresie I. Eibl-Eibesfeldt intensywnie zajmował się badaniem zachowania ssaków. Do swoich badań włączył wówczas tupaje, karłowate mangusty i małpy. Przygotował także jeden $z$ pierwszych podręczników etologii zwierzat pt. Zarys porównawczego badania nad zachowaniem (EIBL-EIBESFELDT 1967, 1998b).

W okresie pracy w Seewiesen odbyła sie druga ekspedycja jachtu „Xarify”, która zajmowała się głównie atolami Malediwów i rybami raf koralowych. Stopniowo Eibl-Eibesfeldt stawał się coraz bardziej znany w środowisku naukowym, a jego sławę ugruntowały prace $z$ zakresu etologii ssaków, pod- 
ręcznik etologii zwierząt, dyskusja nad rola zachowań wrodzonych i uczenia się, a także książki o pierwszej i drugiej ekspedycji „Xarify" (EIBL-EIBESFELDT 1964, 1965, 1982, 1985, 1998a).

Od poczatku lat 60. badania nad zachowaniem się zwierząt morskich i ssaków przestały wyraźnie zadowalać Eibla-Eibesfeldta, kierujacego swoje zainteresowania na zachowanie się człowieka, szczególnie w życiu codziennym. W tym celu wspólnie $z$ Hansem Hassem rozwinęli metodę dokumentacji filmowej, której głównym celem stał się kulturowo-porównawczy program dokumentacyjny ludzkiego zachowania (EIBL-EIBESFELDT 1976b, 1984b). Szczególna wage przywiazywano do badań kultury ludów pierwotnych, które nie miały kontaktów $z$ nowoczesna cywilizacją. Badania nad dziećmi głuchoniewidomymi, odciętymi od głównych informacji środowiskowych, pozwoliły stwierdzić znaczenie zachowań wrodzonych u niemowląt i małych dzieci.

\section{BADANIA TERENOWE ZACHOWANIA LUDÓW PIERWOTNYCH I POZAEUROPEJSKICH}

Począwszy od 1968 r. Eibl-Eibesfeldt rozwinał program długookresowych badań ludów pierwotnych (EIBL-EIBESFELDT 1966, 1967, 1998b). Wojowniczy lud Yanomami stał się szybko ulubionym obiektem badań. Od 1975 r. trwały badania ludu Eipo na Nowej Gwinei, stanowiącego przykład życia „neolitycznych” rolników, oraz Buszmenów $z$ pustyni Kalahari, modelu społeczeństwa łowiecko-zbierackiego. Ciekawy okazał się także lud Himba $z$ północnej Namibii, przykład społeczeństw pasterskich, a także Trobriandczycy, badani już przez Bronisława Malinowskiego, zajmujacy się ogrodnictwem i rybołówstwem, którzy zachowali wiele tradycyjnych zwyczajów i świąt. Z kolei Balijczycy uchodza za przykład zaawansowanego społeczeństwa rolniczego, które rozwinęło się bez wpływu kultury europejskiej.

Eibl-Eibesfeldt i jego współpracownicy nakręcili ponad $230 \mathrm{~km}$ materiałów filmowych $z$ życia ludów pierwotnych. Oryginały filmów znajduja się w archiwum Towarzystwa Maxa Plancka w Getyndze. Badania te dowiodły wiele uniwersaliów w ludzkim zachowaniu, podobna strukturę świąt i rytuałów, wiele analogii i homologii między zachowaniem się zwierząt i ludzi. Zbierano informacje o sposobie pozdrawiania się ludzi, zajmowano się wymiana czułości pomiędzy matka a dzieckiem, badano zabawy i spory między rodzeństwem. Dla Eibla-Eibesfeldta szczególnie interesujaca była rola filogenetycznych przystosowań w zachowaniu społecznym człowieka. Okazało się, że wiele mimicznych ruchów twarzy ma charakter wrodzony. Stąd też możliwa jest pozajęzykowa komunikacja pomiędzy ludźmi różnych kultur. Dotyczy to także wielu naturalnych ludzkich skłonności (tzw. apetencji). W ujęciu Eibla-Eibesfeldta, „filogenetyczne przystosowania, które jeszcze dzisiaj wyznaczaja nasze zachowania, rozwinęły się $w$ długim czasie, gdy nasi przodkowie żyli w małych grupach jako łowcy i zbieracze" (EIBL-EIBESFELDT 1991b, 1993b), tak więc możemy przyjąć „że nasze zachowanie rozwinęło się jako przystosowanie do takiego sposobu życia”. W ciagu ostatnich dziesięciu tysięcy lat człowiek prawie się nie zmienił, pod względem biologicznym, pomimo że stworzył cywilizację techniczna, wielkie miasta, anonimowe masowe społeczeństwa. Biologiczne dziedzictwo, tradycja kulturowa $\mathrm{i}$ indywidualne doświadczenia kształtują wspólnie rzeczywiste zachowania człowieka.

\section{WYBRANE PROBLEMY ETOLOGII CZEOWIEKA}

Irenäus Eibl-Eibesfeldt opublikował szereg ksiązek, w których spopularyzował dotychczasowe osiagnięcia etologii człowieka. Do najważniejszych $z$ nich należy Zarys etologii człowieka, opublikowany w 1984 r. W tym liczacym prawie 1000 stron dziele autor przedstawił teoretyczne podstawy biologii ludzkiego zachowania, uwzględniając nie tylko osiagnięcia etologii, ale także dyscyplin pokrewnych, majacych znaczenie w zrozumieniu ludzkiego zachowania (psychologia, etnologia, socjologia, nauka o kulturze, prymatologia i antropologia biologiczna).

Od 1971 r. odbywały sie coroczne spotkania badaczy zajmujacych się biologia ludzkiego zachowania, co doprowadziło do utworzeni Międzynarodowego Towarzystwa Etologii Człowieka (International Society of Human Ethology), którego przewodniczacym w 1986 r. został Eibl-Eibesfeldt. Tę funkcję sprawowal do $1993 \mathrm{r}$.

Ksiażka K. Lorenza Tak zwane zło ukształtowała wiele uproszczonych opinii o badaniach etologicznych. W odpowiedzi Eibl-Eibesfeldt napisał ksiażkę Miłość $i$ nienawiść, w której rozprawił się z przypisywana fałszywie etologom „koncepcja bestia-humana" (EIBL-EIBESFELDT 1970, 1993a). Ludów pierwotnych nie można uważać za całkowicie odmiennych od ludzi cywilizacji współczesnej. Znacznie bardziej trafna wydaje się opinia, że: „Sa oni pod pewnymi względami inni niż my, chociaż zdumiewająco do nas podobni" (EIBL-EIBESFELDT 1992a, 1994). W nawiązaniu kontaktów $z$ ludźmi pierwotnymi dużą rolę odgrywały podarunki (siekiery, 
noże domowe, szklane perły), a także pomoc medyczna, świadczona zwłaszcza przez prof. Wulfa Schiefenhövela, należącego do najbliższych współpracowników Eibla-Eibesfeldta (EIBL-EIBESFELDT I WSPÓŁAUT. 1989).

Wiele ciekawych danych o ludzkim zachowaniu dostarczyły badania prowadzone w przedszkolach. Problemami tymi zajmował się głównie Karl Grammer, należący także do najwybitniejszych uczniów Eibla-Eibesfeldta. Badania dzieci w przedszkolach wykazały wiele interesujacych procesów samoorganizacji społecznej. Ciekawe było kształtowanie stosunków przyjaźni, a także stosunków „przewodzenia” w grupie, oparte na tzw. strukturze uwagi, znanej również $z$ badań nad naczelnymi. Duże zainteresowanie wzbudziły także badania nad stosunkami społecznymi w nowoczesnych miastach. Prowadziło to do ukształtowania się tzw. etologii miasta. W tym ostatnim wypadku etolodzy razem $z$ architektami zaczęli nawet projektować architekturę najbardziej odpowiadajacca potrzebom człowieka gwarantujacca zdrowie i dobre samopoczucie.

Odmienny charakter ma etologia sztuki. Między innymi podjęto badania tzw. maszkaronów na starych kościołach europejskich. Przedstawiaja one demoniczne postacie, podobne do demonów znanych $\mathrm{w}$ innych kulturach. Etologia sztuki zajmuje się problematyka należaca tradycyjnie do nauk humanistycznych, gdyż sztuka uchodzi powszechnie za działalność specyficznie ludzką. Okazało się jednak, że także zwierzęta mają swoista wrażliwość artystyczna, a szympansy mogac nawet malować (EIBL-EIBESFELDT i SÜTTERLIN 1992).

Duża wage przywiazywał Eibl-Eibesfeldt do badań nad porównaniem zachowań zwierząt i człowieka. Czołowa rolę odgrywaja tutaj badania szympansów, najbliższych genetycznie krewniaków człowieka. W tym celu utrzymywał ścisłe kontakty naukowe $z$ Jane Goodall, najwybitniejsza znawczynia życia szympansów (rezerwat Gombe nad Jeziorem Tanganika). Badania szympansów w ogrodach zoologicznych prowadza najczęściej do błędnych wniosków. Obecnie wiele populacji szympansów zagrożonych jest gospodarczą ekspansją tamtejszej ludności, a także chwytaniem młodych szympansów do badań naukowych, szczególnie farmakologicznych. Szympansy wykazują często zdumiewające podobieństwo do zachowań człowieka (m.in. terytorialne rozgraniczenia, ksenofobia, zachowania przy powitaniu). Pomiędzy szympansami trwaja niekiedy gwałtowne walki o dominacje w grupie, a pomiędzy grupami działania agresywne, przypominajace prymitywne wojny. Zachowanie się bonobo, szympansa karłowatego $z$ Afryki Środkowej, jest jeszcze bardziej podobne do zachowań człowieka. Badali je w warunkach naturalnych dwaj współpracownicy Eibla-Eibesfeldta.

Etologia i jej wyniki naukowe ciesza sie powszechnym uznaniem w kołach naukowych, czego wyrazem była nagroda Nobla w 1973 r. dla Konrada Lorenza, Nikolaasa Tinbergena i Karla von Frischa. Natomiast w 1981 r. nagrodę Nobla otrzymali neuroetolodzy Roger Sperry, David Hubel i Torsten Wiesel.

W latach 70. ukształtowała się w Stanach Zjednoczonych socjobiologia badajaca zachowania społeczne zwierzat i ludzi. Momentem przełomowym w rozwoju socjobiologii zwierzat i człowieka była praca Edwarda O. Wilsona Sociobiology. The New Synthesis (WiLson 1975), która stanowiła syntezę dokonań innych znanych socjobiologów: W. Hamiltona, Ch. Wiliamsa, J. Maynarda-Smitha i R. Triversa. W ujęciu socjobiologów zachowanie społeczne zwierzat służy maksymalizacji rozpowszechnienia własnych genów. Początkowo Eibl-Eibesfeldt odnosił się krytycznie do badań i koncepcji teoretycznych socjobiologii, ale później uznał ich znaczenie dla wyjaśniania zachowania społecznego. Znacznie wcześniej wagę socjobiologii dla badań nad zachowaniem zaakceptował inny wybitny uczeń Konrada Lorenza, Wolfgang Wickler (WICKLER i SEIBT 1977).

\section{WSPÓŁCZESNE ZAGROŻENIA SPOŁECZNE I EKOLOGICZNE LUDZKOSCI}

Obok wielu opracowań ściśle biologicznych, Irenaüs Eibl-Eibesfeldt jest też autorem interesujacych książek o charakterze filozoficzno-społecznym, dotyczacych podstawowych problemów społeczeństwa, gospodarki i ochrony środowiska. W swoich pracach nie unikał trudnych problemów społecznych i ekologicznych zwiazanych $z$ gwałtownymi zmianami ludzkiego zachowania w wyniku rozwoju gospodarki, kultury, zmiany miejsca człowieka w przyrodzie i w społeczeństwie (EIBL-EIBESFELDT 1970, 1993a). Głębszej próby wyjaśnienia współczesnej sytuacji człowieka poszukuje Eibl-Eibesfeldt w uwarunkowaniach ewolucyjnych rozwoju gatunku ludzkiego, a więc w procesach jego filogenezy. Gatunek ludzki zachowuje się często, według Eibla-Eibesfeldta, jakby nadal żył w hordach łowieckich okresu lodowcowego, kiedy to bezwzględna konkurencja decydowała o przeżyciu grupy. Zachowanie konkurencyjne we współczesnej gospodarce, polityce i społeczeństwie zagraża bezpośrednio zniszczeniem przyrodniczych podstaw życia (EIBL-EIBESFELDT 1988c, 1997b). Dla przetrwania człowieka konieczny staje się etos 
przeżycia, który wykorzystywałby takie pozytywne właściwości jak: troska o potomstwo, odpowiedzialność za rodzinę, czy dażenie do zachowania zasobów przyrody.

Społeczne zachowanie się człowieka wyznaczone jest, według Eibla-Eibesfeldta, w większym zakresie przez filogenetyczne przystosowania niż zachowanie wobec środowiska pozagatunkowego. Podstawowe cechy ludzkiego zachowania rozwinęły się bowiem już w okresie paleolitu, gdy nasi przodkowie prowadzili życie łowców i zbieraczy w małych społecznościach. Okres łowiecko-zbieracki obejmowal aż 98\% historii gatunku ludzkiego. Filogenetyczne dziedzictwo przejawia się najpełniej w takich uczuciach jak: miłość, nienawiść, strach, zazdrość. Uwarunkowania filogenetyczne znajduja wyraz w takich potrzebach człowieka jak: rozgraniczanie się grup, skłonność do terytorializmu, dażenie do dominacji społecznej. Ogromny rozwój kulturowy zmienia jednak szybko społeczne i ekologiczne uwarunkowania życia człowieka.

Etologia człowieka ukształtowała się ostatecznie dopiero w latach 60. XX w. Pomimo stosunkowo krótkiej historii, można wyróżnić 3 etapy rozwoju badań biologicznych nad zachowaniem: etologię klasyczna, etologię genetyczna i socjobiologię (KoŚMICKI 1988). Socjobiologia za pomoca swoich twierdzeń o selekcji krewniaczej i koncepcji inclusive fitness (ogólnej wartości przystosowawczej) wyjaśniła w kategoriach ewolucyjnych przyczyny rozwoju zachowań społecznych, a w tym $i$ altruistycznych, u zwierzat i ludzi. Obecnie problematyka etologii klasycznej, etologii genetycznej i socjobiologii obejmuje całość biologicznych badań nad zachowaniem. Współczesna etologia i socjobiologia traktuja zachowania zwierzat jako najbardziej plastyczny element i ważny czynnik wpływający na ewolucję. W przypadku człowieka istotne znaczenie ma rozwój kultury, a koewolucja genów i kultury charakteryzuje osobliwość gatunku ludzkiego (LUMSDEN i WILSON 1981). Człowiek, w przeciwieństwie do większości zwierzat, zdolny jest do wszechstronnego przystosowania do warunków przyrodniczych. Nie jest on pod względem biologicznym specjalista, ale generalista. Jednak człowiek do swojego przeżycia potrzebuje kultury (A. GEHLEN).

Filogeneza człowieka odbywała się w innym wymiarze czasowym niż współczesna działalność gospodarcza. Niektórzy ekonomiści przyjmuja dzisiaj naturalna selekcję jako wzorzec dla działań gospodarczych. Zakładaja oni jednak zbyt krótkie okresy czasowe i zapominaja o długookresowych skutkach takiej ryzykownej strategii. Ludzka działalność nie może być jednak bezpośrednio wyprowadzona $z$ przyrody (WICKLER i SEIBT 1977).

Poszczególne problemy zachowania można więc rozpatrywać zarówno w kategoriach przyczynowości bezpośredniej (ang. proximate causation), jak i ostatecznej (ang. ultimate causation). Według poglądów samych socjobiologów, uzyskanie zadawalającego wyjaśnienia zachowania łączy zarówno bezpośrednie, jak i ostateczne jego przyczyny.

Powstanie większych społeczności wywołało rozwój trwałego przywództwa, aparatu państwowego i powstanie prawa. W dużych społeczeństwach istotne znaczenie ma utożsamienie się $z$ symbolami i podatność na indoktrynację. Tworzenie się wielkich grup następowało poprzez odwoływanie się do apeli rodzinnych, gdzie podstawowe znaczenie miał często wspólny przodek. Rozróżnienie My i Oni pozostaje nadal istotne w anonimowych dużych społeczeństwach, a wizją wroga posługują się nadal przywódcy polityczni i religijni.

Gwałtowny kulturowy rozwój człowieka w ciagu ostatnich 15.000 lat doprowadził do krytycznej sytuacji w funkcjonowaniu filogenetycznych wzorców zachowania. W zmienionych warunkach kulturowych szczególnie groźne staje się zaprogramowanie na istniejąca konkurencję i ludzkie dażenie do władzy, bowiem dla człowieka charakterystyczne jest oportunistyczne, podstawowe nastawienie do środowiska, aby wykorzystać w sposób maksymalny istniejaca szansę bez względu na późniejsze skutki. Jest charakterystyczne, że sukces w konkurencji nagradzany jest wyrzutem hormonów, a radość $z$ odniesienia sukcesu powoduje mało krytyczne zachowania. Stąd też współcześnie w archaicznych krótkookresowych strategiach konkurencyjnych zagrożone sa podstawowe zasoby i życie przyszłych pokoleń.

Najbardziej negatywne skutki krótkookresowego myślenia widoczne sa między innymi w rolnictwie, przemyśle i polityce migracyjnej. Rolnictwo w ciagu wieków rozwinęło różne reguły zachowania podstawowych warunków ekologicznych dla następnych pokoleń. W ciagu ostatnich 30 lat sytuacja jednak uległa zasadniczym zmianom. Obecnie, zamiast rolnictwa tradycyjnego (chłopskiego), rozwija się szybko przemysłowa monokulturowa uprawa roli i masowy chów zwierzat. Pojawiają się ogromne niebezpieczeństwa dla gleb, a także organizmów glebowych. Masowy chów zwierząt prowadzi wprost do... masowej hodowli patogenów wirusowych i rozpowszechnienia się wielu groźnych chorób. Gąbczasta encefalopatia bydła (ang. bovine spongiform encephalopathy, BSE) może stanowić jedynie ostrzeżenie przed przy- 
szłościa ludzkiego pożywienia. Jak zauważa Eibl-Eibesfeldt: „Masowy chów zwierząt nie jest odpowiedzialny ani społecznie, ani ekonomicznie, ani ze względów zdrowotnych" (EIBL-EIBESFELDT 1998c, 2000:90). Współczesne państwa europejskie i Unia Europejska ponosza ogromne ryzyko związane ze skutkami takiego rozwoju rolnictwa.

W wyniku potężnego rozwoju nowych technologii epoki informatycznej doszło do internacjonalizacji rynków finansowych i ograniczenia przeszkód w handlu międzynarodowym. Doprowadziło to szybko do rozwoju globalnego rynku produkcji i usług. Zjawisko to, określane jako globalizacja, ma ogromny wpływ na współczesna gospodarkę i społeczeństwo. W ujęciu Eibla-Eibesfeldta, zwiąek państw w obrębie Unii Europejskiej powinien się przeciwstawić negatywnym skutkom globalizacji, a jednocześnie wykorzystać pozytywnie jej osiagnięcia.

Ludność uprzemysłowionych krajów Europy, USA, Kanady i Japonii żyje we względnym dobrobycie, co wynika $z$ wykorzystywania kopalnych nośników energii. Jednak zasoby ropy naftowej wystarcza jedynie na 150 lat (EIBL-EIBESFELDT 1998c, 2000). W coraz bardziej przeludnionym świecie nasila się zjawisko nędzy i skłonność do migracji do krajów Europy Zachodniej. Jak twierdzi Eibl-Eibesfeldt: „Każda wspólnota solidarnościowa reprezentuje przede wszystkim własne interesy. W tym celu zostaliśmy zaprogramowani przez długa historię filogenezy" (EIBL-EIBESFELDT 1998c, 2000). Różnice w obyczajach i życiu codziennym zaostrzaja przeciwieństwa pomiędzy ludnością miejscowa a migrantami.

Pojawia się więc podstawowy problem dalszego przetrwania ludzkości w trzecim tysiącleciu. Sugerowane są dwie możliwości: procesy samoregulacji przyrody oraz rozsąne planowanie własnej przyszłości. Pierwsza możliwość byłaby bardzo bolesna, gdyż prowadziłaby do załamania się obecnej liczby ludności i pojawienia się ogólnego chaosu społeczno-politycznego. Oznaki takiego rozwoju sa już zreszta coraz bardziej widoczne na niektórych obszarach świata, zwłaszcza na Bliskim Wschodzie i w Afryce. Pokój społeczny i zachowanie środowiska naturalnego możliwe sa jednak tylko w takiej przestrzeni gospodarczej, gdzie utrzymuje się porównywalny poziom dochodów oraz podobne normy ekologiczne i społeczne. Jedynie takie wspólnoty, które gospodaruja świadomie, z myśla o przyszłości moga się połączyć w wielkoobszarowe strefy pokoju i wspólnych działań gospodarczych. Na takich obszarach może dokonywać się wyrównywanie warunków gospodarczych i społecznych.
Ważna książką Eibla-Eibesfeldta jest praca Człowiek - ryzykujaca istota. O historii naturalnej ludzkiej nierozumności (EIBL-EIBESFELDT 1988c, 1997b), w której omawia różnorodne przystosowania filogenetyczne w zakresie postrzegania, przetwarzania informacji, sposobu myślenia i zachowania ludzi. Stwierdza on: „Badania ostatnich dziesiątków lat pokazały, że zwłaszcza nasze zachowania społeczne, ale także nasz sposób myślenia i postrzegania, sa $\mathrm{w}$ decydującej mierze współokreślone przez przystosowania filogenetyczne" (EIBL-EIBESFELDT 1988c, 1997b). Nasuwaja się więc pytania: Czy gatunek ludzki ma jeszcze szansę przetrwać w przyszłości? Co przeszkadza ludziom, aby „bardziej rozumnie” postępowali w otaczającym ich świecie? Odpowiedzi na nie należy szukać, zdaniem Eibla-Eibesfeldta, w naszym dziedzictwie biologicznym. Pierwotnie człowiek był przystosowany do niewielkich liczbowo społeczności, a także łowiecko-zbierackiego sposobu życia. Przystosowania takie okazują się często niewystarczające do warunków współczesnego masowego i anonimowego społeczeństwa oraz postępującej technicyzacji i informatyzacji życia. Współczesny człowiek żyje w świecie, który sam stworzył, a który stał się, pod wieloma względami, dla niego nieodpowiedni.

Do najważniejszych zagrożeń współczesnej ludzkości Eibl-Eibesfeldt zalicza: zagrożenie przez strach, dażenie do władzy i ograniczenie ludzkiej wolności, nadmierna skłonność do „dobra” i "cnoty”, przemoc i wojnę, a w końcu fatalna dynamikę ludzkich wynalazków i organizacji.

Wraz $z$ rozwojem społeczeństwa masowego narasta anonimowość stosunków międzyludzkich oraz zwiększa się agresja i strach we wzajemnych stosunkach społecznych. Nadmierny strach wywołuje skłonność do autorytarnej władzy i zagrożenie liberalno-demokratycznej formy rząów. Ludzie traca wtedy łatwo własną indywidualność i samodzielność myślenia oraz podporządkowuja się demagogicznym (populistycznym) przywódcom, którzy „gwarantuja” prawo, porządek i sprawiedliwość. Przykładowo, idea tabula rasa i przekonanie, że wszystkie różnice między ludźmi wynikaja $z$ odmiennego wychowania, zostały już dawno zakwestionowane przez naukowców, chociaż nadal utrzymują się w społeczeństwie. Podobnie, jako fałszywe naukowo i szkodliwe społecznie, ocenia Eibl-Eibesfeldt różnorodne tendencje społeczne skierowane przeciwko współczesnym osiągnięciom naukowym (np. próby wprowadzania tzw. naukowego kreacjonizmu odrzucajacego teorię ewolucji biologicznej).

Duże niebezpieczeństwa wynikają $z$ własnej dynamiki niektórych odkryć i wynalaz- 
ków. Zaczynają one niejako żyć „własnym życiem", prowadząc do zagrożeń bytu ludzkości. Największa skłonność do rozbudowy wykazuja zwłaszcza takie instytucje jak: armia i biurokracja. Instytucje społeczne, dążacc do zaspokojenia wszystkich podstawowych potrzeb, kieruja ogół ludności na „dziecięcy” etap rozwoju całkowitej od nich zależności. Podsumowując można stwierdzić, że:

W ujęciu Irenäusa Eibla-Eibesfeldta, społeczne zachowania człowieka wyznaczone sa nadal przez filogenetyczne przystosowania powstałe w okresie paleolitu, chociaż obecnie odbywaja się w całkowicie odmiennych warunkach społeczno-ekonomicznych i technicznych.

Społeczeństwa pierwotne różnią się zasadniczo od nowoczesnych społeczeństw przemysłowych, które opierają się na coraz bardziej przyspieszonej ewolucji kulturowej, a zwłaszcza ekonomicznej.

Do najważniejszych zagrożeń współczesnej ludzkości zalicza Eibl-Eibesfeldt: zagrożenia przez strach, co prowadzi do narastania konkurencji i różnych form agresji, dażenie do władzy i ograniczenie ludzkiej wolności m.in. przez łatwość różnorodnej indoktrynacji, nadmierne skłonność do „dobra” i „cnoty”, rozpowszechnione zjawiska przemocy i wojen, własna dynamikę ludzkich wynalazków i rozwoju organizacji.

Współczesny człowiek żyje w gospodarce i społeczeństwie, który sam stworzył, chociaż są dla niego, pod wieloma względami, nieodpowiedne i zagrażaja dalszemu trwaniu społeczeństwa i biosfery.

Potrzebny staje się odwrót od krótkookresowego myślenia i rozwój strategii długookresowego, w znaczeniu etosu, przetrwania następnych pokoleń. Najbardziej negatywne skutki krótkookresowego myślenia stają się widoczne m.in. w rolnictwie, eksploatacji zasobów naturalnych, energetyce i polityce migracyjnej.

Według Irenäusa Eibla-Eibesfeldta, etologia wywiera coraz większy wpływ na filozoficzna teorię poznania (epistemologię). Ludzki aparat poznania jest przy tym odzwierciedleniem obiektywnego świata zewnętrznego, z którym „koresponduje”. W ciagu ostatnich lat rozwinęła się ewolucyjna teoria poznania, w ramach której ukształtowała się także etologia poznawcza. W ten sposób etologia oddziałuje coraz bardziej na cała filozofię. Inna dziedziną filozofii, na która wpływa etologia, jest etyka. Zgodnie $z$ poglądami etologów, zachowania moralne pełnia funkcję biologicznych uwarunkowań i moga się jedynie adekwatne rozwijać na „bazie” biologicznej, gdyż dyskusja o moralności bez uwzględnienia jej skutków biologicznych jest pozbawiona sensu. Zgodnie $z$ twierdzeniami etologów w zachowaniu współczesnego człowieka tkwi nadal potężna porcja „moralności epoki kamiennej", co może być niebezpieczne w warunkach współczesnej cywilizacji.

\section{Streszczenie}

Zmarły w dniu 2 czerwca 2018 r. prof. Irenäus Eibl-Eibesfeldt należy do najwybitniejszych współczesnych biologów zajmujących się problematyką zachowań zwierząt i ludzi. Był twórca etologii człowieka. Rozwinął program długookresowych badań ludów pierwotnych: Yanomami, Eipo, Buszmenów, Himba, Trobriandczyków Balijczyków. Jego dorobek obejmuje 19 ksiażek i około 500 artykułów naukowych, w których stwierdził m.in., że ludzie posiadaja przystosowanie filogenetyczne w zakresie postrzegania, przetwarzania informacji, sposobu myślenia i ludzkiego zachowania.

Eibl-Eibesfeldt był też autorem publikacji o charakterze filozoficzno-społecznym, w których podejmował podstawowe problemy dotyczace społeczeństwa, gospodarki i ochrony środowiska.

\section{PUBLIKACJE KSIAŻKOWE}

PROF. IRENÄUSA EIBLA-EIBESFELDTA

\section{AUTORSKIE:}

Galapagos, die Arche Noah im Pazifik, 1969. Piper, München; 1991a. Weltbildverlag, Augsburg.

Im Reich der tausend Atolle, 1964. Piper, München; 1998a. Dtv, München.

Haie, 1965. Neptun Bücherei Kosmos, Frankfurt/M.

Ethologie. Die Biologie des Verhaltens, 1966. Akad. Verlagsges. Athenaion, Frankfurt/M.

Grundriss der vergleichenden Verhaltensforschung, 1967, 1998b. Piper, München.

Liebe und Hass. Zur Naturgeschichte elementarer Verhaltensweisen, 1970, 1993a. Piper, München.

Die Ko-Buschmanngesellschaft, 1972. Piper, München.

Der vorprogrammierte Mensch. Das Ererbte als bestimmender Faktor im menschlichen Verhalten, 1973. Molden, Wien; 1976a, 1984a. Dtv., München; 1986. Orion Heimreiter, Kiel.

Krieg und Frieden. Aus der Sicht der Verhaltensforschung, 1975, 1990, 1996. Piper, München.

Menschenforschung auf neuen Wegen, 1976b. Molden, Wien; 1984b. Goldmann, München.

Die Malediven. Paradies im Indischen Ozean, 1982, 1985. Piper, München.

Die Biologie des menschlichen Verhaltens. Grundriss der Humanethologie, 1984c, 1997a. Piper, München.

Der Mensch, das riskierte Wesen. Zur Naturgeschichte menschlicher Unvernunft, 1988c, 1997b. Piper, München.

Human Ethology, 1989. Aldine de Gruyter, New York.

Das verbindende Erbe, 1991b. Kiepenheuer \& Witsch, Köln; 1993b. Heyne, München.

Fallgruben der Evolution. Der Mensch zwischen Natur und Kultur, 1991c. Wiener Vorlesungen im Rathaus. Picus) Wien.

Und grün des Lebens goldner Baum. Erfahrungen eines Naturforschers, 1992. Kiepenheuer \& Witsch, Köln; 1994a. Heyne, München. 
Wider die Misstrauensgesellschaft. Streitschrift für eine bessere Zukunft, 1994b, 1997c. Piper, München.

Die Falle des Kurzzeitdenkens, 1998, 2000. Piper, München.

\section{KSIAŻKI W JEZYKU POLSKIM:}

Galapagos. Arka Noego pośród Pacyfiku, 1969. Iskry, Warszawa. (Wyd. I); 1988. Śląsk, Katowice. (Wyd. II zmienione).

Miłość i nienawiść. Historia naturalna elementarnych sposobów zachowania się, 1987. PWN, Warszawa. (Wyd. I); 1998. PIW, Warszawa (Wyd. II).

\section{WSPÓŁAUTORSKIE (PIERWSZY WSPÓŁAUTOR):}

EIBL-EIBESFELdT I., SÜTTERLIN CH., 1992. Im Banne der Angst. Piper, München.

EIBL-EIBESFELDT I., SCHIEFENHÖVEL W., HEESCHEN V., 1989. Kommunikation bei den Eipo. Dietrich Reimer, Berlin.

\section{WSPÓŁAUTORSKIE (DALSZY WSPÓŁAUTOR):}

Hass H., Eibl-EibesfeldT I., 1977. Der Hai, Legende eines Mörders. Bertelsmann, München. Pod nowym tytułem: Wie Haie wirklich sind, 1986. Dtv, München.

SÜTTERLIN CH., SALTER F. K., EIBL-EIBESFELDT I., 2001. Zu Person und Werke. Peter Lang $\mathrm{GmbH}$, Frankfurt am Main et al.

\section{REDAKCJA PRAC ZBIOROWYCH:}

EiBl-EIBESFELDT I., SALTER F. (Hrsg.), 1998. Indoctrinability Ideology and Warfare. Berghahn Books, New York-Oxford.

Eibl-EibesfeldT I., HASS H., FreisitZer K., GeHMACHER E., GLÜCK H. (Hrsg.), 1985. Stadt und Lebensqualität. Deutsche Verlagsanstalt, Stuttgart.

KuRTH G., EIBL-EIBESFEldT I. (Hrsg.), 1975. Hominisation und Verhalten. Gustav Fischer, Stuttgart.
ROLINSKI K., EIBL-EIBESFELDT I. (Hrsg.), 1990. Gewalt in unserer Gesellschaft. Gutachten für das Bayerische Staatsministerium des Innern. Duncker und Humblot, Berlin.

\section{MATERIAŁY ŻRÓDŁOWE WYKORZYSTANE DO PRZYGOTOWANIA TEKSTU}

KośmiCKI E., 1986. Biologiczne koncepcje zachowania. PWN, Warszawa-Poznań

KoŚMICKI E., 1988. Etologiczne i socjobiologiczne rozwiniecia teorii ewolucji. Studium metodologiczne. Wyd. Akademii Rolniczej w Poznaniu, Poznań.

MeYer P., 1981. Evolution und Gewalt. Ansätze zu einer biosoziologischen Synthese. Parey, Berlin-Hamburg.

Meyer P. 2010. Menschliche Gesellschaft im Lichte der Zweiten Darwinschen Revolution. Evolutionäre und kulturalistische Deutungen im Widerstreit. LIT VERLAG Dr W. Hopf, Berlin-München-Wien-Zürich-London.

LUMSDEN CH., WILSON E. O., 1981. Genes, Mind and Culture. Harvard University Press, Cambridge Mass.-London.

OEHLER J. (Hrsg.), 2010. Der Mensch. Evolution, Natur und Kultur. Beiträge zu unseren heutigen Menschenbild. Springer, Heidelberg-Dordrecht-London-New York.

TINBERGEN N., 1976. Badania nad instynktem. PWN, Warszawa.

VOlAND E., 2000. Grundriss der Soziobiologie. Spektrum, 2. Aufl., Heidelberg-Berlin.

WiCKLER W., SEIBT U., 1977. Das Prinzip Eigennutz. Hoffmann u. Campe, Hamburg.

Wilson E. O., 1975. Sociobiology: The New Synthesis. Cambridge Mass. University Press, Cambridge Mass.

Wuketits F. M., 1997. Soziobiologie. Die Macht der Gene und die Evolution sozialen Verhaltens. Spektrum, Heidelberg-Berlin-Oxford.

KOSMOS Vol. 68, 1, 5-12, 2019

\section{EUGENIUSZ KoŚMICKI}

Department of Social Sciences and Pedagogy, Faculty of Economics and Social Sciences, Poznan University of Life Sciences, 28 Wojska Polskiego Str., 60-637 Poznań,-mail: e.h.kosm@gmail.com

ON THE LIFE AND WORKS OF AN AUSTRIAN ETHOLOGIST PROF. IRENÄUS EIBL-EIBESFELDT

(15 JUNE 1928 - 2 JUNE 2018)

\section{Summary}

The late Professor Irenäus Eibl-Eibesfeldt, who passed away on 2 June 2018, was one of the most outstanding contemporary biologists investigating problems of animal and human behaviour. He was the founder of human ethology. He developed the long-term research programme investigating indigenous peoples: Yanomami, Eipo, San (Bushmen), Himba, as well as Trobriand and Bali tribes. His literary output comprises 19 books and around 500 scientific papers, in which he stated, among other things, that humans are phylogenetically adapted to perceive, process information, think and exhibit human behaviour.

Eibl-Eibesfeldt was also the author of publications in the field of philosophy and social studies, in which he discussed basic problems concerning the society, economy and environmental protection. 